\title{
INTRAPERITONEAL TEMPERATURE OF PIGLETS IN THE FIRST THREE POSTNATAL WEEKS AS MEASURED BY RADIOTELEMETRY
}

\author{
E. BARANYIOVÁ ${ }^{\prime}$, A. HOLUB, R. L. HULLINGER ${ }^{2}$ \\ ${ }^{1}$ Department of Biochemistry, University of Veterinary and Pharmaceutical Sciences and Veterinary Research \\ Institute, Brno, Czech Republic; ${ }^{2}$ Department of Basic Medical Sciences, School of Veterinary Medicine, \\ Purdue University, West Lafayette, IN, USA
}

Received July 7, 1996

Accepted February 10, 1997

\begin{abstract}
Baranyiová E., A. Holub, R. L. Hullinger: Intraperitoneal Temperature of Piglets in the First Three Postnatal Weeks as Measured by Radiotelemetry. Acta vet. Brno, 1997, 66:3-8.

Intraperitoneal temperature (IT) was determined in early-weaned piglets of both sexes to day 21 , using radiotelemetry. Ten piglets (five weaned on the second, five on the third day after birth), were used in the study. They were reared individually in cages, of fered a liquid diet for suckling at 2-h intervals 9 times a day. They were placed in a temperature-controlled room with L:D regime of 12:12 h. Audio signals from intraperitoneally implanted transmitters (Minimitter Co., Sunriver, OR, USA) were converted to body temperature using calibration data. A total of 1,963 daily measurements taken between 06.00 and $22.00 \mathrm{~h}$ show that in the first two postnatal weeks the mean daily IT rose significantly $(\mathrm{P}<0.05)$ with advancing age from $39.8 \pm 0.1^{\circ} \mathrm{C}$ to $40.5^{\circ} \mathrm{C}$.

At the beginning of the second week, there was a transient IT decrease, followed by another increase; IT did not change thereafter. There were also diurnal changes in IT observed in the light phase, especially during the morning hours. IT was also affected by gender. In males the mean daily IT was higher, though not significantly, during the entire experimental period.

During dietary intake there was a small temporary increase in IT. An IT elevation occurred in several piglets suffering from transient diarrhoea.

Radiotelemetric procedures with unrestrained animals exclude measurement errors resulting from direct contact with the measuring techniques/devices and the excitement due to contact with experimenters. Radiotelemetry opens new technical possibilities of a reliable, undisturbed recording of body temperature in piglets.
\end{abstract}

Early weaning, core body temperature, individual rearing, temperature regulation, radiotelemetry

Body temperature in pigs, an important clinical diagnostic index, has been often reported in the literature. It has long been one of basic criteria for evaluating the individual health status in adult swine and has also been studied in piglets. Numerous investigations have shown that body temperature at birth is lower than that of adult individuals. These studies were summarized by Holub (1968) and Mount (1968). The authors analyzed the effects of cold environment on newborn piglets, resulting in rapid decreases of their rectal temperature, which often portends death. These studies focused on the first perinatal hours. In other studies, evidence was presented that, although the rectal temperature of the piglet does increase with advancing age, it is lower than previously reported, immediately after birth, but also several weeks following birth. Others have shown that in older piglets, rectal temperature rapidly decreases when piglets are exposed to environmental cold, returning to pre-exposure levels slower than in adults. This is a consequence of the progressive development of thermoregulatory ability, a function which develops only postnatally (Holub et al. 1957abc; Holub 1959, 1960b, 1968; Mount 1959, 1961, 1965, 1968, 1971; Close 1992; Herpin and Le Dividich 1995).

In piglets, body temperature is usually measured per rectum. Its fluctuations, when measured experimentally, may be caused not only by functional changes, but also by the measuring techniques. These artifactual changes in recorded body temperature have been 
shown to be due to simple handling manipulations, procedures connected with restraint, and changes in the environment, such as the mere presence of an unknown caretaker or experimenter (Vacek 1924).

More recently, body temperature has been measured using thermocouples. The newest technologies employ remote procedures that are free from the above-mentioned artifacts of measurement. We therefore used radiotelemetry to measure the intraperitoneal temperature (IT) of piglets in the early postnatal period, eliminating the influences of restraint or other contact.

\section{Materials and Methods}

\section{Animals and managementes}

Ten crossbred (Landrace-Yorkshire-Piétrain) piglets ( 6 males, 4 females) were selected from two litters at the Swine Research Farm Unit (Purdue Department of Animal Science). The first group of piglets $(n=5)$ was kept under conventional confinement conditions during postnatal day one with approximately $12 \mathrm{~h}$ colostrum suckling available; a second group ( $n=5$, from another litter) was removed to the laboratory on day three. Both sows were clinically healthy.

Piglets were weighed and placed individually in stainless steel cages $(76 \times 122 \times 173 \mathrm{~cm})$, the floors of which were about $30 \%$ covered with an electrical, temperature-controlled warming pad (Stairfield heating pad, Osborne Industries, Osborne, KS, USA), allowing them to select their thermal environment. The piglets were thus separated from the sow and from each other so that no physical contact was possible. The cages were arranged such that they could hear, but not see each other. All were kept in the same, temperature-controlled room, at $20^{\circ} \mathrm{C}$ and at a relative humidity of $60 \%$. Fluorescent lighting was on by timer $06.00-18.00 \mathrm{~h}$; no other light entered the room. Every effort was made to eliminate noise from the environment; caretakers and experimenters were familiar to the piglets. Environment enrichment ,toys" were continually available to each piglet.

Piglets were individually offered a milk-replacer diet Soweena containing $11,980 \mathrm{~kJ}_{\mathrm{kg}} \mathrm{k}^{-1}$ metabolizable energy, $25.08 \%$ proteins, and $12.32 \%$ lipids (analysis kindly provided by Dr. Arentson of Milk Specialties Company, Dundee, IL, USA). One part of dry formula powder was reconstituted in four parts warm water daily. The reconstituted diet was refrigerated at $4{ }^{\circ} \mathrm{C}$ for no longer than $10 \mathrm{~h}$. The diet was warmed in a waterbath to $38-40{ }^{\circ} \mathrm{C}$ and offered by bottle to each piglet for suckling ad libitum, nine times daily, from $06.00-22.00 \mathrm{~h}$, at $2 \mathrm{~h}$ intervals, followed by an $8 \mathrm{~h}$ night pause as previously described (Holub 1968, 1994; Holub and Baranyiová 1989; Baranyiová and Holub 1993; Holub and Doležel 1994). Diet intake was measured by weighing the bottle before and after each feeding. Feeding bottles and utensils were kept clean and disinfected; the cages and floor of the animal housing room were cleaned and disinfected daily.

\section{Temperature measurement and transmission apparatus}

Before the experiment, each piglet was surgically equipped (first group on postnatal day 2; second group on postnatal day 4) with an intraperitoneal temperature transmitter, ,minimitter“, weighing between 12.0 and 14.8 g (Mini-Mitter thermistors, model MV, Mini-Mitter Co., Sunriver, OR, USA), to measure core body temperature. These thermistors were custom-made, manufactured as waterproof and biologically inert (sealed and coated in silicone rubber) and calibrated in a waterbath over a range of $31.8-42.8^{\circ} \mathrm{C}$ in increments of $0.1{ }^{\circ} \mathrm{C}$. The metal cages caused no signal interference. Minimitter output was transduced as audible beeps from a battery-operated AM radio. Signals by these audio pulses were counted per unit time with a stopwatch and converted to body temperature from calibration charts provided by the manufacturer. After the experiment, the minimitters were recovered and checked by recalibration by the manufacturer; no changes were detected in the devices as a result of the experimental procedure.

\section{Surgical procedure}

Surgery was performed aseptically under isofluorane inhalation anesthesia. An identified and chemically sterilized minimitter was inserted without fixation in the peritoneal cavity through a standard $5-6 \mathrm{~cm}$ incision approach by the linea alba. Sutures were removed 6 days later; there were no resulting surgical complications. Procedures were performed by the food animal surgery section of the Veterinary Teaching Hospital. All details of the experimental procedures had prior approval of the Purdue University Animal Care and Use Committee.

At the end of the experiment, the piglets were euthanatized using pentobarbital sodium overdose and necropsied. The positions of minimitters in the peritoneal cavity were recorded before their removal. All minimitters were unattached and presumably free to be passively moved about the cavity. In five piglets they remained in the ventral or ventrolateral portion of the cavity, in two animals dorsal, near the root of the mesentery and enveloped by the omentum, in one lateral, and in two dorsolateral. Fibrin tags were found around the transmitters; in three animals small abscesses were found at the suture site. They were unrelated to the minimitters.

Statistics. Student's t-test was used to assess for variance in IT. 


\section{Results and Discussion}

Analysis of our data revealed that the live body mass of experimental piglets increased in a similar although less rapid manner than in other studies using this type of early weaning (Holub 1964, 1968, 1994; Holub and Baranyiová 1989). By this radiotelemetric method, we observed the mean daily IT to be lowest in the two-day-old $\left(39.8 \pm 0.1^{\circ} \mathrm{C}\right)$ and highest in the 14-day-old piglets $\left(40.5 \pm 0.1{ }^{\circ} \mathrm{C}\right)$, increasing by $0.7^{\circ} \mathrm{C}$ (Fig. 1). Day-to-day differences in IT were statistically significant only sporadically: between days 2 and 4 IT increased $(P<0.05)$, between days 9 and 11 it declined $(P<0.05)$, and between days 11 and 14 it again increased $(P<0.01)$. In older piglets (days $15-21)$ there were no significant differences in mean daily IT.

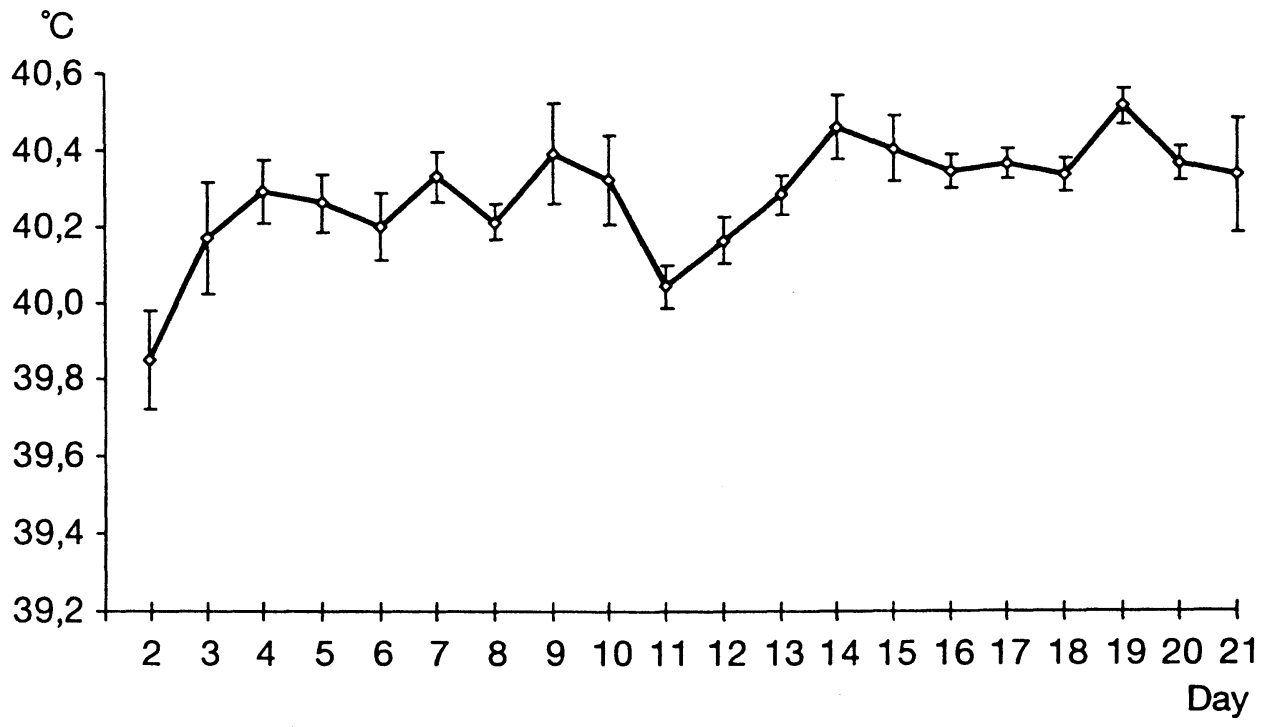

Fig. 1. Mean daily IT of piglets in the first three postnatal weeks

We also measured the circadian changes in IT between 06.00 and $22.00 \mathrm{~h}$ at two-hour intervals. In the morning hours IT increased, a trend that became significant only on day 3 (between 06.00 and $10.00 \mathrm{~h}$ and between 18.00 and $20.00 \mathrm{~h}, \mathrm{P}<0.01$ ), days 4 and 5 (between 08.00 and $12.00 \mathrm{~h}$ ), day 6 (between 06.00 and $20.00 \mathrm{~h}, \mathrm{P}<0.01$ ), day 7 (between 08.00 and $18.00 \mathrm{~h}, \mathrm{P}<0.05$ ), day 11 (between 06.00 and $12.00 \mathrm{~h}$ and between 16.00 and $18.00 \mathrm{~h}$, $\mathrm{P}<0.05$ ), day 14 (between 08.00 and $12.00 \mathrm{~h}, \mathrm{P}<0.01$ ), and day 15 (between 06.00 and $18.00 \mathrm{~h}, \mathrm{P}<0.05$ ). During day 3 (between 12.00 and $18.00 \mathrm{~h}, \mathrm{P}<0.05$ ) and day 14 (between 12.00 and $18.00 \mathrm{~h}, \mathrm{P}<0.05)$ the IT decreased. These statistically significant daily oscillations in IT of piglets were observed only in the first postnatal week, but they occurred daily. In the second week they were observed only during two days; in the third week only once at the beginning of the week. In older animals these diurnal oscillations no longer occurred (Table 1).

There were remarkable, though not significant gender specific differences in daily IT, being consistently high in males than females during the entire experimental period (Fig. 2).

IT was further affected by diet consumption. Suckling in piglets is connected with a considerable thermogenic muscular activity, as previously reported (Holub 1994; 
Table 1

Mean daily oscillations of intraperitoneal temperature in piglets in the first three postnatal weeks

\begin{tabular}{|c|c|}
\hline Hour & ${ }^{\circ} \mathrm{C}$ \\
\hline 6 & $40.05 \pm 0.04$ \\
8 & $40.21 \pm 0.06$ \\
10 & $40.34 \pm 0.06$ \\
12 & $40.24 \pm 0.07$ \\
14 & $40.24 \pm 0.07$ \\
16 & $40.28 \pm 0.04$ \\
18 & $40.28 \pm 0.04$ \\
20 & $40.35 \pm 0.03$ \\
22 & $40.38 \pm 0.05$ \\
\hline
\end{tabular}

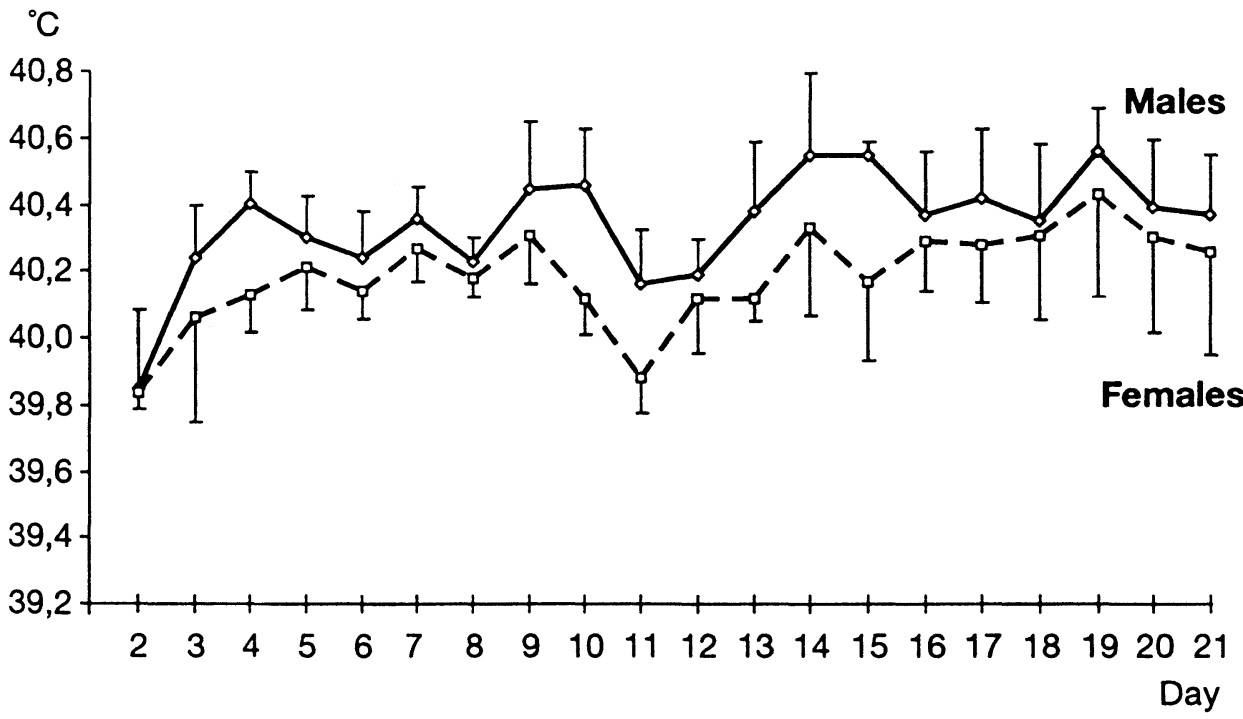

Fig. 2. Gender differences in mean daily IT of piglets in the first three postnatal weeks

Holub and Doležel 1994). In this experiment we detected a tendency of IT to increase, sometimes by only $0.1^{\circ} \mathrm{C}$, but on other occasions it rose by more than $0.4^{\circ} \mathrm{C}$. These changes were not statistically significant.

In our 9-day-old piglets a transient diarrhoea developed. IT of affected piglets reached $40.89 \pm 0.19^{\circ} \mathrm{C}$ and was significantly higher $(\mathrm{P}<0.05)$ than mean IT of piglets not suffering from diarrhoea. This elevation may be considered a sign of impaired gastrointestinal function. A similar febrile effect has been demonstrated by enterotoxins and various cytokines of inflammation in other species (Kent et al. 1992; Dantzer 1993; Johnson et al. 1993; Klir et al. 1994, 1997).

Body temperature in piglets is subject to great variation depending on the site of measurement (Holub et al. 1957abc; Holub 1959, 1968, 1971; Mount 1968, Kotrbáček et al. 1982; Haaland et al. 1996). Its fluctuations, especially on the body surface, are related to radiation and connected with changes in ambient temperature (Holub 1958, 1960ab; Lávička et al. 1960). 
IT represents accurately the „core body temperature“. Its telemetric recording does not interfere with the behaviour of animals and, thus, may be repeated many times. Our radiotelemetric data reflects undisturbed accurate and reliable measurements of the influence of age changes and diurnal fluctuations on IT. We also report that IT is influenced by gender and the suckling activity.

Our data linking IT age changes confirm the well-documented progressive development of thermoregulation in piglets in the early postnatal period (Holub 1968). Measuring IT by radiotelemetry has been used successfully in other species of laboratory and farm animals (Spencer et al. 1976; Theissen and Kittrell 1980; Varosi et al. 1990; Johnson and von Borell 1994; Kundig et al. 1994) and in pigs to measure elevations in body temperature due to external stimuli (Vacek 1924). This is a new, powerful tool for study of an important response/diagnostic parameter as a manifestation of change in the physiology of piglets via their core body temperature.

\section{Radiotelemetricky měřená intraabdominální teplota selat v prvních třech týdnech po narození}

Deset selat odstavených druhého $(n=5)$ a třetího $(n=5)$ dne života po narození jsme po tři týdny individuálně odchovávali v klimatizované místnosti osvětlené od 6 do $18 \mathrm{~h}$, na tekuté dietě, která jim byla nabízena $\mathrm{k}$ sání devětkrát denně ve dvouhodinových intervalech. Z voperovaných tělísek jsme radiotelemetricky registrovali impulzy a z jejich frekvence mezi 6. a 22. h jsme vypočítávali intraabdominální teplotu (IT). Z celkem 1963 telemetrických měření vyplývá, že v prvých dvou týdnech po narození jejich průměrná denní IT s přibývajícím věkem průkazně stoupá, z 39,8 na $40,5^{\circ} \mathrm{C}$. Na začátku druhého týdne se snižuje, krátce na to se opět zvyšuje, ale v dalším údobí se prủkazně nemění. Kolísá i diurnálně, ve světlé části dne, a to zvlášt v hodinách dopoledních; v prvním týdnu každodenně a méně často i v týdnu druhém. IT selat je ovlivňována i sexem. U kanečkủ byly denní průměrné IT po celé sledované období, byt neprůkazně, vyšší než u prasniček. I sání diety ji zvyšuje, a to kolísavě a nikoli průkazně. Stoupá též při průjmech selat v 9. dni života.

Distanční radiotelemetrický postup vylučuje chyby působené kontaktem s měřící technikou a lidmi a otevírá i u selat nové možnosti spolehlivé, nerušící a nerušené registrace tělesné teploty.

\section{Acknowledgements}

The experiment was conducted in the Veterinary Laboratory Animal Care Facilities at the West Lafayette campus. Surgical procedures were kindly arranged by Dr. J. F. Fessler. Professor of Surgery. This study was made possible by a J.W. Fulbright Scholarship to E. Baranyiová and the generous support of the D. R. Gore Trust.

\section{References}

BARANYIOVÁ, E., HOLUB, A. 1993: The effects of diarrhoea on food intake of piglets weaned on the first day after birth. Vet. Med. Praha 38:659-665

CLOSE, W. H. 1992: Thermoregulation in piglets: environmental and metabolic consequences. In: Neonatal survival and growth. British Society on Animal Production. Occasional Publication .No 15. Leeds 1992. p. 25-33

DANTZER, R. 1993: Neuroimmune basis of sickness behaviour. Proceedings of the International Congress of Applied Ethology (Ed. M. Nichelmann, H.K. Wierenga. and S. Braun) Berlin 1993:115-122

HAALAND, K., STEEN, P. A.. THORESEN, M. 1996: Cerebral, tympanic and colonic thermometry in the piglet. Reprod. Fert. Develop. 8:125-128

HERPIN. P., LE DIVIDICH. J. 1995: Thermoregulation and the environment. In: The neonatal pig. Development and survival. CAB. Walling ford. pp. 57-95

HOLUB. A. 1958: Vliv chladu na teplotu kủže u selat. Sb. VŠZL Brno B. 6 (27):291-302

HOLUB. A. 1959: Teplota těla selat po ochlazení. Sb. VŠZL Brno B, 7 (28):141-145 
HOLUB, A.1960a: Vývoj teploty kůže u selat I. Vet. Med. Praha 5 (33):101-108

HOLUB, A. 1960b: Vliv chladu na selata. Veterinářství 10:452-456

HOLUB, A. 1964: Váhové přirůstky selat chovaných na semisyntetické vysokokalorické dietě v prvním měsíci Života. Živoč. Výroba 9 (37):539-544

HOLUB. A. 1968: Funkční periodizace časného postnatálního vývoje u selat. VF VŠZ Bmo, 125 p.

HOLUB, A. 1971: Problem of neonatal pig survival. Acta vet. Brno 40, Suppl. 2:13-17

HOLUB, A. 1994: Prasnice a selata - nutrǐ̌ní interakce. Vet. Med. - Czech 39:117-132

HOLUB, A.. BARANYIOVÁ, E. 1989: Radiačně ošetřená mléčná krmná směs ve výživě časně odstavených selat. Vet. Med. Praha 34:545-552

HOLUB, A., DOLEŽEL, F. 1994: Influence of daily sucking frequency on the consumption of liquid diet in earlyweaned piglets. Acta vet. Brno 63:121-128

HOLUB, A., FORMAN, Z., JEŽKOVÁ, D. 1957a: Teplota těla u selat. Veterinářství 7:214-216

HOLUB. A., FORMAN, Z., JEŽKOVÁ, D. 1957b: Development of chemical thermoregulation in piglets. Nature 180:858-859

HOLUB, A.. FORMAN, Z., JEŽKOVÁ, D. 1957c: Vývoj thermogenese u selat. Vet. Med. Praha 2 (30):181-190

JOHNSON. R.W., von BORELL. E. 1994: Lipopolysaccharide-induced sickness behavior in pigs is inhibited by pretreatment wit indomethacin. J. Anim. Sci. 72:309-314

KENT, S., BLUTHÉ, R.-M., KELLEY, K.W., DANTZER, R. 1992: Sickness behaviour as a new target for drug development. Trends Pharmacol. Sci. 13-24

KLIR, J. J., McCLELLAN, J. L., KLUGER, M. J. 1994: Interleukin-1 causes the increase in anterior hypothalamic interleukin-6 during LPS-induced fever in rats. Am. J. Physiol. 266, R1845-R1848

KLIR, J. J., SHAHBAZIAN, L. M., MATTERI, R. L., FRITSCHE, K. L., BECKER, B. A. 1977: Effects of thermal environment on response to acute peripheral lipopolysaccharide challenge exposure in neonatal pigs. AJVR, 58:364-368

KOTRBÁČEK. V., HOLUB, A. 1982: Věkové změny tělesné teploty a teploty kůže selat v rưzném, komplexně definovaném tepelném prostředí. Čs. Fysiol. 31:464

KUNDIG, H., BINDER, H., THUN, R., NEUKOMM, P. A., BUCKLAR, H., BALLMER, E., ZEROBIN, K. 1994: Temperaturmessung beim Rind mittels 1-Kanal-Telemetrie. Mh. Vet.-Med. 49:163-169

LÁVIČKA, M.. NĚMEĆEK. L., HOLUB, A. 1960: Vývoj teploty kủže u selat II. Vet. Med. Praha 5 (33):109-118

MOUNT, L. E. 1959: The metabolic rate of the new-born pig in relation to environmental temperature and the age. J. Physiol. 147:333-345

MOUNT, L. E. 1961: Metabolic rate and body temperature in the newly born. In: Ciba Foundation symposium on somatic stability in the newly born. London, pp. 117-130

MOUNT, L. E. 1965: The young pig and its physical environment. In: Energy metabolism. Proceedings of the 3rd symposium held at Troon, Scotland, May 1964. London, pp. 379-385

MOUNT, L. E. 1968 : The climatic physiology of the pig. Edward Arnold, London, 271 p.

MOUNT, L. E.. INGRAM, D. L. 1971: The pig as a laboratory animal. Academic Press, London and New York. $175 \mathrm{p}$.

NUESSLEIN. B., SCHMIDT, I. 1990: Development of circadian cycle of core temperature in juvenile rats. Amer. J. Physiol. 259:R270-R276

SPENCER, F., SHIRER, H. W., YOCHIM, J. M.1976: Core temperature in the female rat: effect of pinealectomy or altered lighting. Amer. J. Physiol. 231:355-360

THIESSEN, D. D., KITTRELL, M. W. 1980: The Harderian gland and thermoregulation in the gerbil (Meriones unguiculatus). Physiol. Behav. 24:417-424

VACEK, T. 1924: Regulace tělové teploty u některých domácích zviřat. II. Regulace tělové teploty u vepře. Biol. Spisy VŠZ Brno 3:1-12

VAROSI, S. M., BRIGMON, R. L., BESCH, E. L. 1990: A simplified telemetry system for monotoring body temperature in small animals. Lab. Anim. Sci. 40:299-302

Address for correspondence:

Doc. MVDr. Eva Baranyiová, CSc.

Department of Biochemistry

University of Veterinary and Pharmaceutical Sciences

Palackého 1-3

61242 Brno

Czech Republic

Phone: 420541562505

Fax: 420541211151

E-mail: baranyi@dior.ics.muni.cz. 